

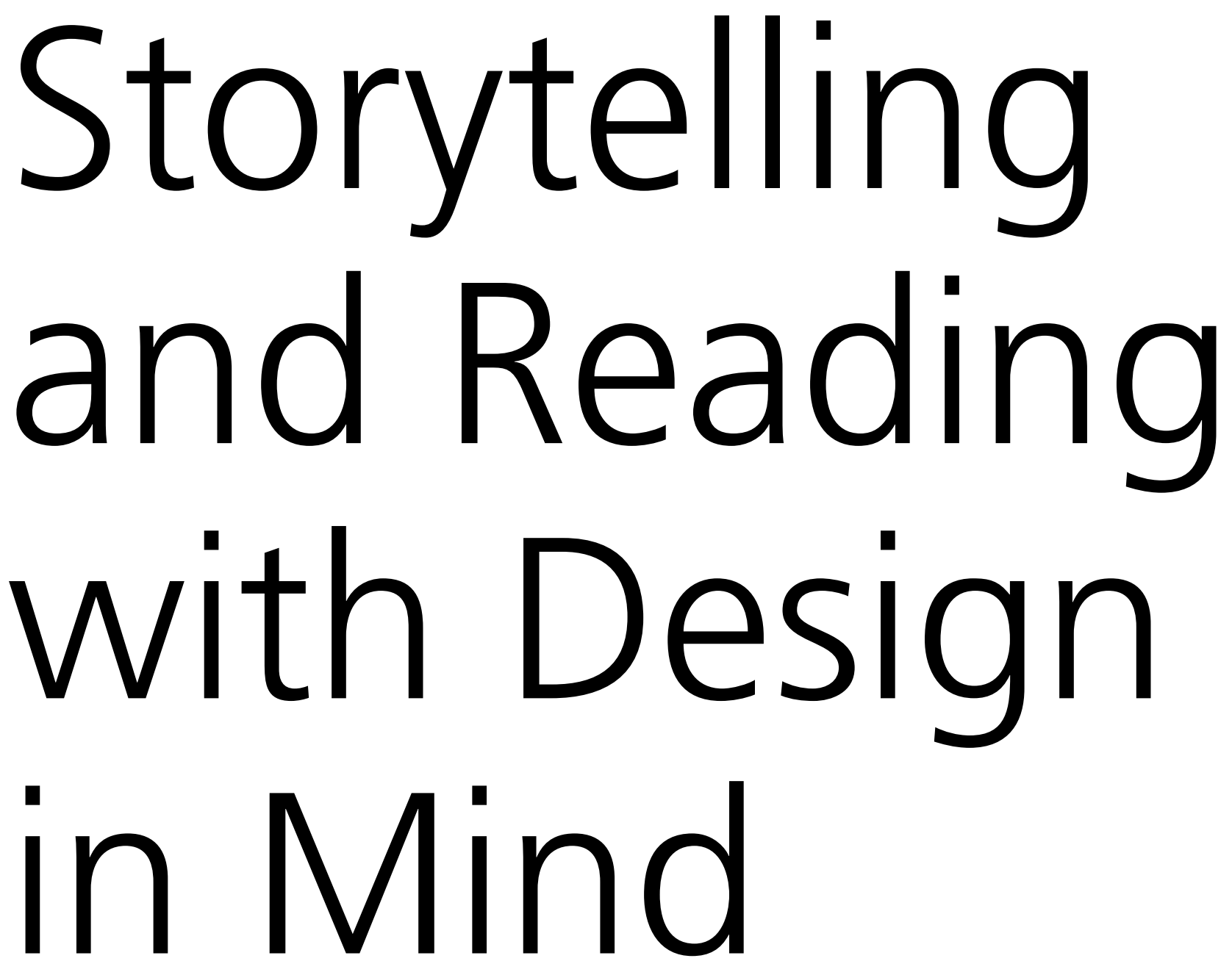

Susan Yelavich 


\section{Storytelling and Reading with Design in Mind ${ }^{1}$}

Susan Yelavich ${ }^{2}$

In this paper, I argue that literature is a fertile source of insight for design research and scholarship-in particular, those stories that explore the mutuality of the sentient and insentient, a mutuality pointing to a new kind of politics. - I mean a politics in which human actors are held accountable- - this despite the new-found liveliness in things inherent in 'thing theory' and related concepts-.

By revealing the qualities and affects of objects and places, - For the sake of brevity, I will use the words "objects" and "places" to encompass all design practices and/or outcomes. - By repositioning them as characters - protagonists and antagonists, these kinds of stories have the capacity provoke the recognition of the activity and outcomes of designing in shaping the social and political. But it is a capacity that needs to be unlocked. The process of mining literature for such knowledge would just be a sort of intellectual gymnastics were it not committed to what literary critic George Steiner calls "the politics of the primary" $(1989,6)$. This is a politics that demands a willingness to meet ourselves and authors in their work, and in doing so, conduct a more fully human exchange.

In Real Presences, Steiner calls for a performative criticism. He argues that in reenacting and thus reinterpreting a work (i.e., Homer's Odyssey as reprised by Dante, Joyce, and others), we ingest that work instead of merely consuming it $(1989,9)$. Furthermore, this particular process of translation entails an ethics of critique, one that calls for "answering" the work at hand responsibly. Steiner would have us actively acknowledge the voice (be it embodied in a text, an object, a piece of music, and so on) that is speaking to us, and not cast it aside for a secondary or tertiary form of criticism of the self-same work. He calls for the same respect for works of art that we accord persons when we answer (rather than ignore) their spoken questions. Literature is one mode of

1 La version original de este texto fue presentada como parte del ciclo DESIS Philosophy Talks. Design For Social Innovation Meets Philosophy, 2015.
2 yelavics@newschool.edu, The New School

MFA, Fine Arts and History, Cranbrook Academy of Art. Associate Professor of Design Studies and Director, MA Design Studies, School of Art and Design History and Theory, Parsons School of Design. 
answering, and the literature that I am concerned with is that which responds to the qualities and capacities of design, which, as the illustrations indicate, continue to preoccupy design today.

\section{To cite just a few examples:}

- In Remembrance of Things Past, Proust isolates an aesthetic experience afforded by a new technology. In this case, it is the telephone, which in the 1920s, requires a pilgrimage to the post office and the invention of a new vocabulary. When the "virgins of the wires" break his connection with his beloved grandmother, the phone becomes an instrument of separation, evoking a painful reminder of her eventual death. But when the technology succeeds, life is not just restored it is changed. His senses operate differently and his behavior changes accordingly. The isolation of sound from image, of voice from face, causes him to speak more sweetly: "what I held in this little bell by ear was our mutual affection (...)" (Proust, $1981,136)$. In these passages, Proust offers a recognition of the unanticipated social and sensory affects of technology_-pressing concerns for designers today.

- Wisława Szymborska's poem The End and the Beginning calls on broken sofa springs and window glass shards to evoke the carelessness with which we discard the consequences of one war for another. When Syzmborska writes that "someone has to tidy up... after "[a] II the cameras have gone" $(1996,178)$, she genders the work of repair done by men and women alike. Might not housekeeping be reconsidered as a kind of designing?

- The Cave by Jose Saramago responds to one of those questions. Namely, how do we come to 'know' matter in the first place? Saramago answers this way:

Anything in the brain-in-our-head that appears to have an instinctive, magical, or supernatural quality — whatever that may mean —is taught to it by the small brains in our fingers. In order for the brain to know what a stone is, the fingers first have to touch it (Saramago, 2002, 66).

Each of these works reveals a dimension of (and possibility for) design. For the purposes of this forum, however, what follows will concentrate more specifically on writings that reveal 


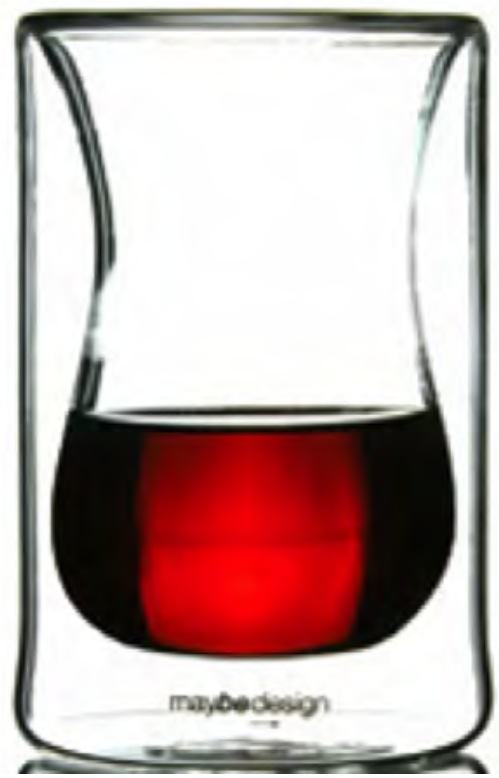

how design (again, in the largest sense of the word) is imbricated in issues of culture, identity, race, and by extension, socio-political systems.

Orhan Pamuk, Charles D'Ambrosio, and Darryl Pinckney are writers whose books are unlikely to be found in a library or bookstore shelved under "design."

-The possible exception is Charles D'Ambrosio's "The Russian Orphanage," which appeared in the fall 2002 issue of Nest: A Quarterly of Interiors. Nest, published in the U.S. by Joseph Holtzman from 1997 to 2004, was itself a rare exception among design magazines.- This is because design is still generally misunderstood as being separate from notions of shaping our being or projecting how we might be in the future-capacities that are, in fact, understood to be within the ambit of literature. Eloquent arguments from design theorists (Buchanan, Dilnot, Fry, Margolin, Manzini, Papanek, et. al.) have countered this instrumental view of design for decades. Literature, however, has the distinct potential of bringing those arguments to even wider audiences, not to mention the possibility for engaging designers in a different way. Literature doesn't instruct. It theorizes and speculates by stealth, under the cover of story. Things, themselves, are literally given voice by Orhan Pamuk; and D'Ambrosio and Pinckney are no strangers to the anthropomorphic. 
These authors use things to speak to particular social conditions in particular places, and, through them, identify shared human desires, anxieties, and behaviors. They rise above parochialisms by activating the tension between the particular and the general, and depending on one's theoretical proclivities, between signifier and signified, between the thing and the object. Their work offers arguments that point to various ways of becoming more fully human, paralleling the ways in which design works (or can work) as a catalyst for agency. Finite resolutions are eschewed in favor of provocative questions.

Case in point: In his novel My Name is Red (1998), Orhan Pamuk uses the tropes of investigation and interrogation as structure and strategy, as both means and end. Ostensibly a detective story about the murder of a miniature painter in $15^{\text {th }}$-century Istanbul, My Name is Red, is, in fact, a debate about eastern and western values, a debate about modernity, conducted through form. Throughout the novel, the idealized conventions of Turkish miniature painting (and its venerable antecedents) are compared both favorably and unfavorably with the realism of painting in Renaissance Venice.

- A Turkish tree-actually a sketch of a tree meant to be part of an illustrated manuscript page-says he feels lost because he is not part of a scene of a story. (He is also literally lost-having been accidentally separated from the manuscript and found in his unfinished state). At the same time, the tree also confesses that he secretly enjoys the idea of being seen as a singular tree. But for all his vacillation, he'd rather be the meaning of a tree (Pamuk 2001/1998, 51) — the meaning that comes from a relational context.

- Conversely, a horse drawn in the Turkish style is aggrieved that he and all horses appear "as if traced with an identical stencil twenty times back to back" (218). Venting his scorn for a feminized east, the horse likens Turkish miniaturists to "ladies" who never leave their houses, never look at real horses, and refrain from drawing the individual features that make him a particular horse.

- A counterfeit coin circulating in Turkey, but made in Venice, draws attention to the hypocrisy of the West's scorn for the copy over the 'original.' All the while the coin regales his listener the pleasures of his life as a copy. (It goes without saying that all Turkish miniatures are copies and made to keep ancient myths and histories not just alive, but intact.) 
The tree's ambivalence, the horse's self-hatred, and the coin's cosmopolitan identity are all surrogates for social responses to conceptions of modernity: continuity or rupture, or a cosmopolitan hybrid of both. The aesthetic debates conducted by Pamuk's characters may seem remote from design as we know it six centuries later, but for the fact that so much of the horrific violence the young $21^{\text {st }}$ century has witnessed flows directly from it. My Name is Red reveals the ways in which tribal, national, and religious conflicts (and compromises) have their own aesthetic dimensions, and are therefore a matter of and for design.

Where Pamuk's book operates on the scale of conflicting cultural geographies compressed within bi-continental Istanbul, Charles D'Ambrosio's journalistic essay Russian Orphanage (2002) is set against ideological geographies that are commensurately monumental-the legacies of Soviet communism and United States capitalism. In this piece for Nest, a nowdefunct quarterly of interiors, D'Ambrosio visits a run-down barracks and former prison camp, now an orphanage in Svir Story, five hours outside of St. Petersburg.

Here, D'Ambrosio locates design as the occasion for spatial tactics and strategies devised by children. A hole punched into a wall between dormitory room's functions as their telephone. The tiny architectural disruption serves as a conduit for the exchange of notes and a substitute for lost familial connections. The physical and institutional edges of the orphanage are softened by the wear and tear of daily contact between feet, shoes, and stair treads, between hands and railings. What in America would appear as "signs of decrepitude" (2012), in this context, are marks of vital social relations within an adoption system that regularly thwarts it. Here, future parents shop for future sons and daughters; most are left behind.

From the modest material witnesses of abandonment and survival-a scrapbook, bottle caps, shared cigarette butts, D'Ambrosio elicits a picture of ideological differences rooted in two different sets of politics that drove the $20^{\text {th }}$ century and are still seeking relevance in the $21^{\text {st }}$. The notion of individualism, which values an "absolute right to an interior self," is absent in the orphanage, where codependency is paramount. Clearly the polarity of values is not raised to evoke nostalgia for communal systems whose failures appear in congealed layers of paint and broken bricks. From a design perspective, one might argue that instead of fetishizing the scabrous, that focus be put on repairs and systems of repairs, and, more 
generally, the values and possibilities of continuity. Being able to recognize that which (and those who) came before us, as part of the palimpsest that is our present, just might make us feel, as the poet Philip Lopate writes, a little less lonely and freakish (1994).

In contrast to the vastness of the territories embraced by Pamuk and D'Ambrosio, the terrain staked out by Darryl Pinckney's High Cotton (1992) is markedly intimate. Likewise, this analysis focuses on only a fraction of Pinckney's novel. Set in the latter half of the $20^{\text {th }}$ century, High Cotton is a coming of age story of a black man, who describes his family's status (upper-middle class African American) as the "Almost Chosen." The human propensity for naming and categorizing, reflected in that qualified moniker, here, takes on a profoundly different measure when applied to matters of race.

On a visit to relatives in the "Old Country" (the American South), Pinckney's narrator describes his elderly Aunt Clara's living room. In this instance, the design information lies less in the particularity of candy dishes, fire screens, and prism lamps, and more in the sum of their parts. The room is a kind of gesamtkunstwerk mirroring a system of racial prejudicesa system internalized by an aging Southern black woman, a system externalized in the arrangement and density of things.

Her house was a zoo of things...a wild preserve for the pedestal sideboard... I was perfectly free to study the living habits of the lyre-backs in the vestibule...

A sign on my mother's face said, "Don't feed the rugs" (Pinckney, 1992, 32-33).

Otherwise commonplace metaphors describing an interior as a cabinet of curiosities take on an entirely different cast, or more accurately "caste," when his mother's face is likened to the sort of regulatory notices found in wildlife parks and urban zoos. (Of course, this is a high-class zoo with lyre-back chairs.) The pointed prose is more than just a reference to the incarceration that was slavery. It illuminates one of its consequences: a social system among African Americans in which some lay claim to the dubiously exalted status of an exotic species.

Here, Pinckney is describing "a family that thought of itself as inhabiting a middle kingdom" (33). The language of classification is deliberate. The sitting room's material occupants-rug, 
chairs, and sideboard-are depicted to echo fictions of race plotted on percentages of blood mixtures. (Aunt Clara describes her grandfather as "seven-eighths Caucasian and one-eighth Negro" (33)). Such numerical formulations were reflected in a less precise but no less affective hierarchy of color. These calculations govern (and are sustained by) Aunt Clara, (and presumably others of the "Almost Chosen), who is prone to observations such as, "Why, you're the darkest one in the family" (35).

Designations such as octoroon and quintroon may sound arcane to the $21^{\text {st }}$ century ear, but they persist in the American social imaginary. In its turn toward the social and systemic, design would do well to examine the less obvious sub-systems and hierarchies contained in terms such as race, class, religion, and gender. Just as design systems iterate and morph through their deployment, so do social categorizations. Admittedly, design, by nature, is interrogatory, predicated on disrupting preconceptions. Yet, none of us are immune to the forces of our own experiences, hence concepts of, race, class, religion and gender. Pinckney's real gift to design may be the intergenerational perspective of his novel. He models a way to see our inheritances - the frameworks designers bring to matters of concern-at once sympathetically and critically. High Cotton makes the case for the vitality of history in the present.

The stories like those of Pamuk, D'Ambrosio, and Pinckney, translated to design, are especially important now that design has been effectively diminished-viewed as either a brand of objects or a brand of management. In evoking the visceral and relational nature of things, behaviors, and desires, literature allows us to more fully comprehend the potency of design. A work of literature can cover a lifetime, indeed, generations of living with and among things, long after they cease to be thought of as design and become part of the fabric of life.

Designers can then extract their work from the immersive environment of story, put that work under close examination, and revise their plotlines accordingly. In the process, literature can help designers with the work of anticipating the effects of what philosopher Peter-Paul Verbeek $(2005,217)$ calls the multistability of objects and their mediations. As we work to tell a new story of our place in the world with a view toward sustainment and a politics of the anthropocene, literature may serve us better than any manifesto of design. 
For in what I will call the literature of things, all relations are reciprocal.

Having said that, it is also true that there are ways in which both literature and design can be construed as supporting actors in the realm of politics. This would seem to have been the view of Hannah Arendt when she wrote:

[A]cting and speaking men need the help of homo faber in his highest capacity, that is, the help of the ... builders or writers, because without them the only product of their activity, the story they enact and tell, would not survive at all (Arendt, 1998/1958, 173).

This is literature and artifice interpreted as a residual of political action and speech. In using the verb "survive," Arendt conjures representations that outlast the ephemeral speech and movement of bodies in space. But design is not to be confined to illustration, nor texts to documentation. They are themselves modes of speech and action, fully capable of projecting alternatives, formulating speculations, and occasioning political and ideological debate. Even in memorializing or standing as three-dimensional records of time past, design can redirect attention to the present.

In Austerlitz, W.G. Sebald would have it do both, and in the process, defeat time altogether. Though at first, Sebald seems to frame design-specifically architecture-through the lens of retrospection. His use of photography might even reinforce Arendt's position that buildings (as with other works produced by homo faber) testify to ideas but do not generate them. Furthermore, Sebald's protagonist is an architectural historian. His journey to recover a past stolen by inhuman politics of purity of the Nazis could be mapped by the landmarks he visits.

At one point, we find him in London's Broad Street Station, then under renovation, where he wanders into an abandoned Ladies' Waiting Room:

In fact, I felt, said Austerlitz, that the waiting room where I stood as if dazzled contained all the hours of my past life, all the expressed and extinguished fears 


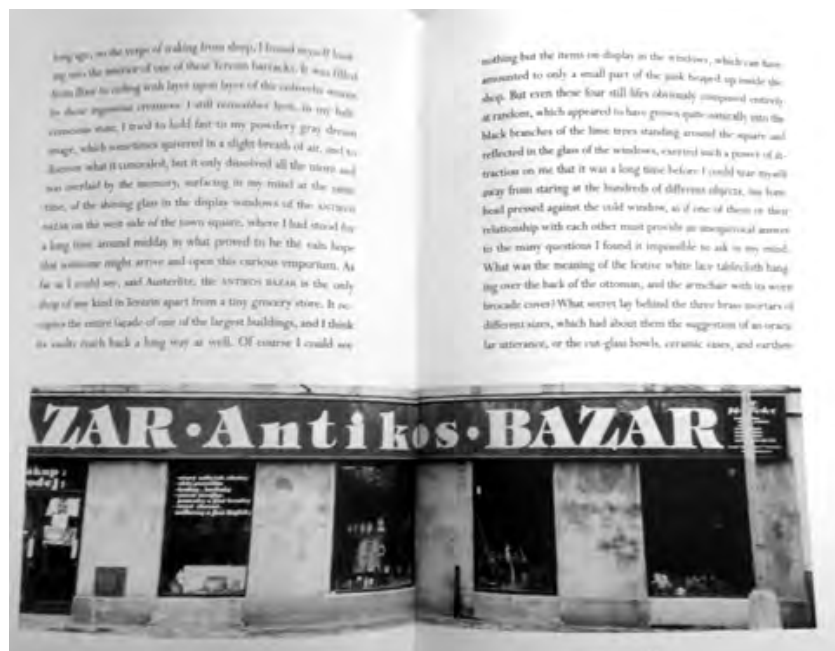

and wishes I had ever entertained, as if the black and white diamond pattern of the stone slabs beneath my feet were the board on which the end game of my life would be played, it covered the entire plane of time (Sebald, 2001, 36).

At this juncture, his memories are stirred by a place, fittingly a place of transit. (Austerlitz had been sent to Wales during the war along with hundreds of other children to remove them from the geography of National Socialist horror.) But the point of memory is as much to explain his existence in the present as it is to discover the fate of his parents.

More pointed is his journey to the Theresienstadt concentration camp from which his mother never emerged. Again, the structures are representative of a horrific past never to be deactivated or given agency, except in memory. But the town of Terezín (now Czech) is something else. In the muteness of the shuttered village, we sense, with Austerlitz, the politics of denial. Sebald gives us a window onto the aesthetic of the political. In doing so, he lends a different interpretation to Arendt's perspective on the work of homo faber, and by extension design. He asks them to bear witness not to embody (or embalm) the politics of speech and action but to continue the conversation and interrogate it going forward. 
STORYTELLING AND READING WITH DESIGN IN MIND

\section{References}

(1999). Attachment in Blades of Grass: The Stories of Lao She. Honolulu: University of Hawai'i Press, 225.

Arendt, H. (1998/1958). The Human Condition, Chicago: University of Chicago, 173.

D'Ambrosio, C. (2002). Russian Orphanage, Nest: A Quarterly of Interiors, Fall 2002.

Lopate, Phillip. (1994). Introduction in The Art of the Personal Essay: An Anthology from the Classical Era to the Present. New York: Anchor Books, XXXII.

Pamuk, O. (2001/1998). My Name is Red. New York: Alfred A. Knopf, 2001.

Pinckney, D. (1992). High Cotton. New York: Farrar, Straus and Giroux.
Proust, M. (1981/1924). Remembrance of Things Past, Book II, New York: Random House.

Saramago, J. (2002). The Cave. New York: Harcourt.

Sebald, W.G. (2001). Austerlitz. Toronto: Alfred A. Knopf Canada.

Steiner, G. (1989). Real Presences, Chicago: University of Chicago Press.

Szymborska, W. (1996). View with a Grain of Sand. London: Faber \& Faber.

Verbeek, P (2005). What Things Do: Philosophical Reflections on Technology, Agency, and Design.

University Park, Penn.: The Pennsylvania State University Press. 